\title{
The Impact of Airtel Money on the Image and Turnover of Airtel Congo Company in the Congolese Market of Mobile Telephony
}

\author{
NGOMAH LE TEMPS Décide Amour Prestige * \\ $\mathrm{PhD}$ in Management Sciences and Engineering/ Specialty: Marketing Management \\ School of Management, Wuhan University of Technology, P.R. China, 430070 \\ letempsdecide@gmail.com \\ ${ }^{*}$ Corresponding author
}

Keywords: Impact, Airtel money, Reputation, Turnover, Mobile telephony, Market.

\begin{abstract}
This article reviews a sharp analysis of the impact of products on the growth of the enterprise in general. It examines in particular: the influence and positive contribution of the Airtel money product over the reputation and the turnover of Airtel Congo. To measure the impact of this product on the brand image and the development of its manufacturer (Airtel Congo), an analytical and comparative study was made between the Airtel Money product and the other products of Airtel Congo. In addition, a comparison with the similar product of the competition namely MTN Mobile Money (MMM) was done. A comparative approach focusing on PCA (Principal Component Analysis) with the help of the Excel software, where Airtel money was used to measure the notoriety or reputation of the Airtel Congo Company, was applied to affirm the hypotheses and solve the problem of this study.
\end{abstract}

\section{Introduction}

Since the abysses of the times, it is undeniably recognized in any market that the product constitutes the element that unites the manufacturer (company) and the consumer (the buyer). In this perspective, marketing researchers have gone so far as to define the market as the place where supply and demand meet (Claude Demeure, 2008) [1]. For Lendrevie, Lévy and Lindon (2009) [2], a market is perceived as a space where supply and demand meet, and every supply in a market is a product. Indeed, if the product is the basis or the origin of the meeting between the offer and the applicant, this implies that it has an important and indispensable feature in this relationship. It seems to be the central element, even the keystone in the relationship between the company and its customers (Yvan Valsecchi, 2009) [3]. Thus, there is a certain complexity to the extent that, the company in manufacturing its product ultimately aims at profit.

However, consumers on their side, wanting perfect satisfaction in the consumption of products, become more and more exigent towards the suppliers. This leads many companies to place emphasis on the quality of the product to be introduced into the market. In this perspective, Yvan Valsecchi (2009) states: "The consumer prefers the product that offers better performance". For Don Junior Ngomah [4] [5] , the company must therefore focus on improving the quality of its production first. Airtel Congo, which is in a so-called competitive market, is directly concerned by this reality.

As a result, the company undertakes profound reflections in the manufacture of its products in order to completely satisfy its customers. But, the satisfaction of the customer in the consumption of the product of his choice leads without any doubt to the reputation of the product and the company which manufactured it; satisfaction stimulates consumers to the act of purchase, hence the growth of the turnover. With the respective financial expansions of 500,000; 1000,100, 1100800, 1200000, 1350000 consumers from 2012 to 2016 (see table 1) [6], Airtel money became the lead product of Airtel Congo, a concept defined by Michael E. Poter, (1998) [7] as a product with a strong contribution in a still growing market or a product with an interesting development potential for the company. It is the dazzling success of this product on the Congolese market of mobile telephony that leads us to conduct this study focused on the following objectives. 


\section{General Objective}

$\checkmark \quad$ Analyze the impact of products on the growth and image of companies.

\section{Specific Objectives}

$\checkmark \quad$ Examine the influence and contribution of the product Airtel money on the turnover and the expertise of the company Airtel Congo.

$\checkmark \quad$ Evaluate the place and reputation of the Airtel money on the Congolese market of the mobile telephony compared to the other products of Airtel Congo and compare its sales force or its level of consumption over competing products.

\section{Problem Statement}

$\checkmark \quad$ What is the impact of products on the growth and image of a company?

$\checkmark$ What is Airtel Money's contribution to the growth of the turnover and the notoriety of Airtel Congo?

$\checkmark$ What is the place of Airtel Money compared to the competing products and other products of Airtel Congo?

\section{Assumptions}

$\checkmark \quad$ The good quality of products (goods and services) of a company can be an added value on the performance, growth and brand image of the company.

$\checkmark$ Airtel money can be a vector that effectively contributes to the growth of Airtel's reputation and turnover in the market of mobile telephony in Congo Brazzaville.

$\checkmark \quad$ The level of consumption of the Airtel Money product can explain its leadership on the other Airtel products and the competing products from other companies.

\section{Research Methodology}

In order to carry on this study, we mainly used three methods: the analytical technique, the survey technique and the documentary technique. These techniques helped us to collect, analyze and interpret the data. In fact, we observed the Congolese market of mobile telephony, consulted some documents dealing directly or indirectly with certain aspects of our research. The different information collected helped us to solve the problems encountered and assumptions of our study.

\section{Product Concept Analysis}

In a simple way, the product concept is defined as a good or service offered in a market by a manufacturer and/or a company in order to satisfy the needs of the consumers. According to Philip Kotler, Kevin Keller and Delphine Manceau (2012) [8], product is anything that can be offered in a market in order to satisfy a need. A product can be a tangible good, a service, an experience, an event, a place, a person, an organization, an idea ... (). For Lendrevie, Levy and London (2012), the product is a good manufactured and marketed by a company. They add that the product is not necessarily a tangible or material good, but it can also have an intangible character, qualified or called service. An insurance contract is a product, as well as a banking service, a hotel night, air transport, a radio show or a telephone subscription. () Therefore, Airtel Money service can be called product.

Moreover, it should be noted that function of a company is based on its product. It is the means by which the enterprise generates its growth and profits. This demonstrates how much the product occupies a preponderant place in the wealth manufacturing process or added values within organizations (companies). Without wanting to put aside the other policies or elements of Jérome McCarthy's theory (1960) [9], namely: price, place and promotion, we simply mean that the product is the culminating, focal, and departure point or the " $\mathrm{A}$ " point, meaning that it is undeniably recognized by all the theorists and experts in marketing-management that one cannot talk about price, place, sales and communication strategies without creating or having a project of manufacturing any product. Otherwise, the other 
elements are useless. Product is actually the starting point, it is through it and because of it a company can afford to fix the other strategies: price, place and promotion. Since it is one of the key elements, if not the key element of the company, it is crucial to take care of its manufacturing to ensure that the other elements (price-place-promotion) accompany it positively.

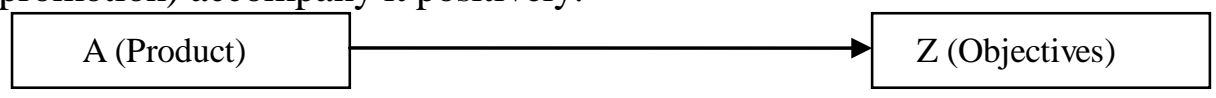

The diagram above reflects the idea that before you get to business strategies, growth, results and company's benefits, everything begins with the product.

\section{Product Description and Data Analysis}

\section{Description of the Airtel Money Product}

Airtel Money is a service that allows you to make money transactions from your phone. It is an electronic wallet and promotes the following operations: payment of invoices, receipt and sending of money, cash deposits, withdrawals, credit purchase for you or third parties, acquiring telephone fixed fee on calls, messages and Internet, do transactions to or from your bank account (BGFI Bank etc. ...)

\section{Product Life Cycle (Airtel Money)}

The life cycle of a product can be defined as the analysis of the major stages of its life, from conception to the final decision to withdraw it from the market (Claude Demeure, 2008). The life cycle of a product is represented by curves called life curves: it is the dynamic representation of its life, the evolution of potential demand over time. Each phase is characterized by its growth rate, sales, profitability, debt, degree of development, market development speed, strategies adopted for each element of the mix.

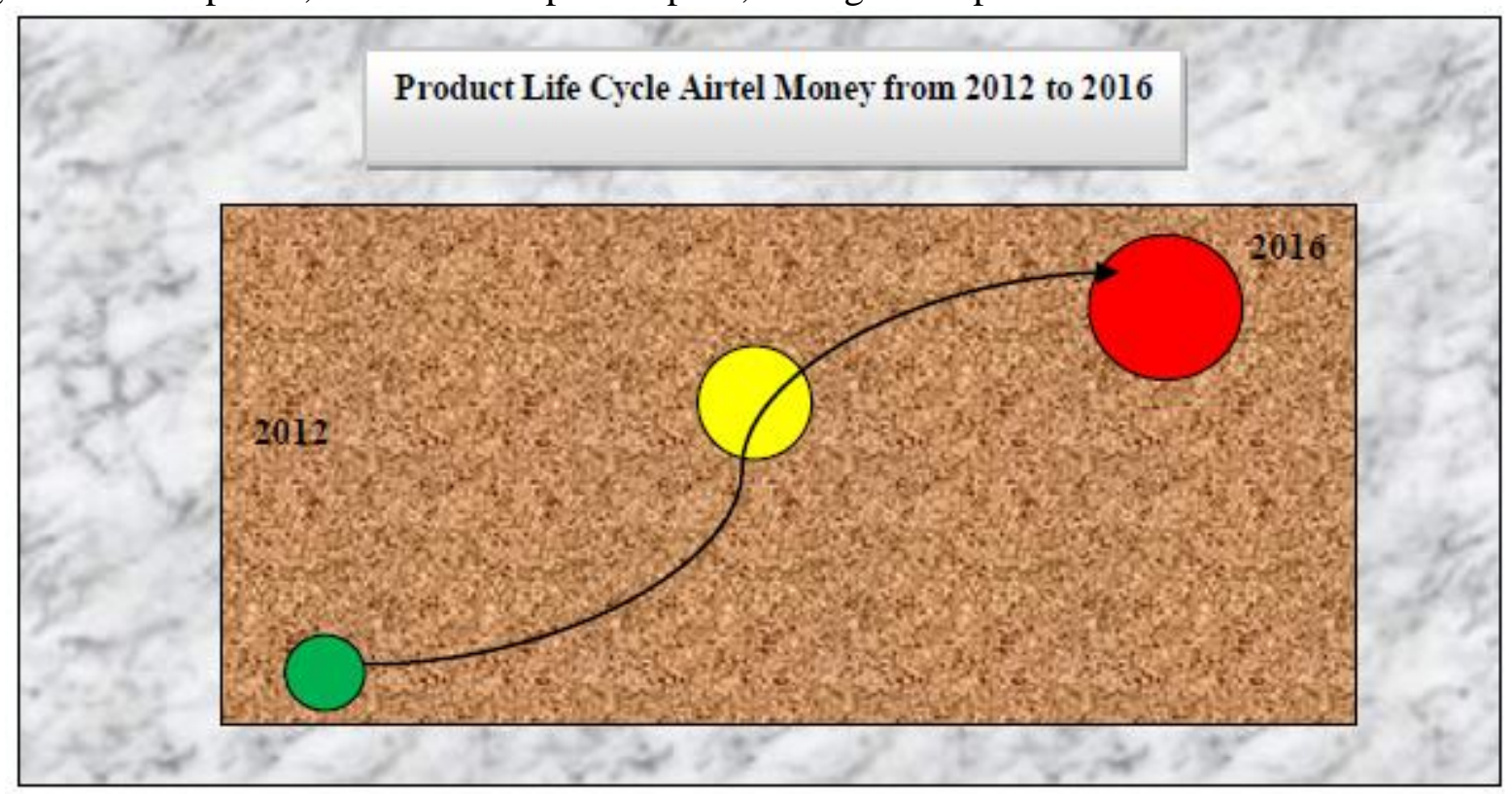

Fig. 1 Life Cycle of Airtel Money

The chart above summarizes the life cycle of the Airtel Money product in a personalized way. It focuses on three main stages: launch, growth and maturity. Indeed, the green dot explains the launch phase of this product, in 2012. In addition, the yellow point defines the phase of growth between 2013 and 2014 . Which means the phase in which the Airtel money product began to experience its expansion, its exponential development in a concurrently stuck environment. Finally, the red dot explains the age of maturity of the product, a step in which Airtel money has achieved its stability, in terms of performance, quality and sales. However, the graph clearly indicates that the Airtel money product is not yet in decline, because Lendrevie (2012), defines and explains the decline phase as a stage in which the product is overtaken by new innovations where sales are inexorably falling, the data in our possession accurately 
explain stability, efficiency and leadership of this product. Hence, there is the absence of the so-called decline stage on our graph.

Moreover, since the dimensions of the three points (balls) explaining the three stages of the life of the Airtel money product are not the same, this implies that the degree or the volume of each point respectively expresses the evolution and the " Impact of the product within the market and within its company. Thus, it should be noted that when a company or manufacturer launches any product, it expects to see the growth and maturity of it, that is its most ardent purpose. However, growth and maturity can be seen when the product has relatively high sales, acquires a certain brand image (notoriety, success) in its competition market, gains considerable market share and imposes its leadership among many other Products whether in direct or indirect competition.

\section{Data Analysis and Results}

\section{Analysis of Competition.}

When you talk about competition, you immediately see a competition between one company and another, producing the same or almost the same products and selling them on the same market. One can also note the competition between the products of the same company, which leads us to use the term "internal competition". Thus, in the context of our study, we will first analyze the internal competition that we have already defined as the competition between the Airtel Money product and the other products of Airtel Congo. This will enable us to measure the impact, the place Airtel money occupies within the company, its contribution to the turnover and brand image of the company. We will then discuss the external competition between Airtel money and the similar products of competitors like MTN Congo with for product MTN mobile money.

\section{Internal Competition and Principal Component Analysis (PCA)}

As the title suggests, internal competition explains the internal challenge, which means the competition or the battle between the products of the same company. Here, we analyze the sales force of each product while comparing it with the product under consideration (Airtel money), to finally deduce the place it occupies within the company and know what is its contribution to the Airtel Congo turnover.

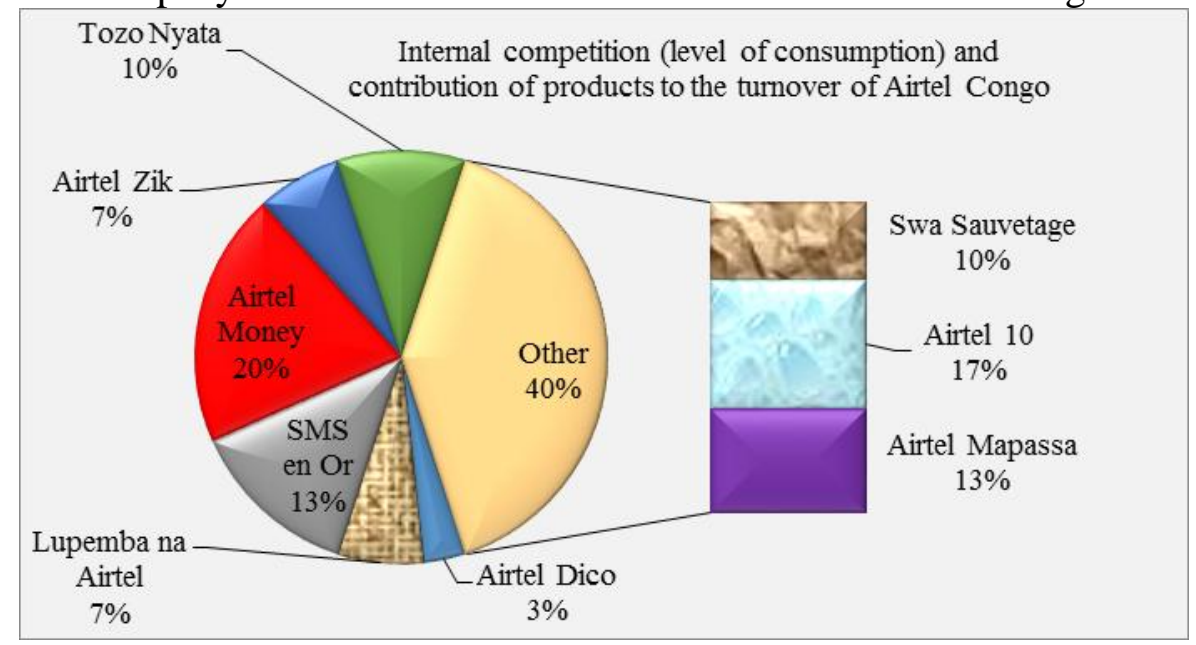

Fig. 2 Competition between Airtel Money and the other products of Airtel Congo

The data shown above in graphic is the representation of the evolution or the level of sale and consumption of the products of Airtel Congo. After a statistical analysis by Excel, it is clear that the product Airtel Money occupies the first place with $20 \%$ of consumption level out of 100 . Next comes Airtel 10, Airtel Mapassa, SMS in Gold, Tozo Nyata, Swa rescue, Airtel zik, Lupemba Na Airtel, Airtel Dico with respectively $17 \%, 13 \%, 13 \%, 10 \%, 10 \%, 7 \%, 7 \%, 3 \%$ sales and contribution to the turnover of Airtel Congo. From this perspective, it should be said that Airtel Money is considered to be among the products analyzed above as the leader, the product that contributes the most to the revenue and reputation 
of Airtel Congo, except traditional services: calls, messages that require the daily purchase of credits (units) from users.

\section{External Competition}

* Airtel Money vs. MTN Mobile Money

Table 1 Comparative analysis between Airtel Money and MTN Mobile Money

\begin{tabular}{|l|l|l|l|l|l|l|}
\hline Consumer & Years & \multicolumn{5}{|l|}{} \\
\hline $\begin{array}{l}\text { Level of } \\
\text { consumption }\end{array}$ & Products & 2012 & 2013 & 2014 & 2015 & 2016 \\
\cline { 2 - 7 } & Airtel Money & 500000 & 1000100 & 1100800 & 1200000 & $\begin{array}{l}135000 \\
0\end{array}$ \\
\cline { 2 - 7 } & $\begin{array}{l}\text { MTN Mobile } \\
\text { Money }\end{array}$ & 600000 & 700000 & 650000 & 710000 & 790000 \\
\hline Total & 1100000 & 1700100 & 1750800 & 1910000 & $\begin{array}{l}214000 \\
0\end{array}$ \\
\hline
\end{tabular}

Note: Source: Operator, Author and ARPCE

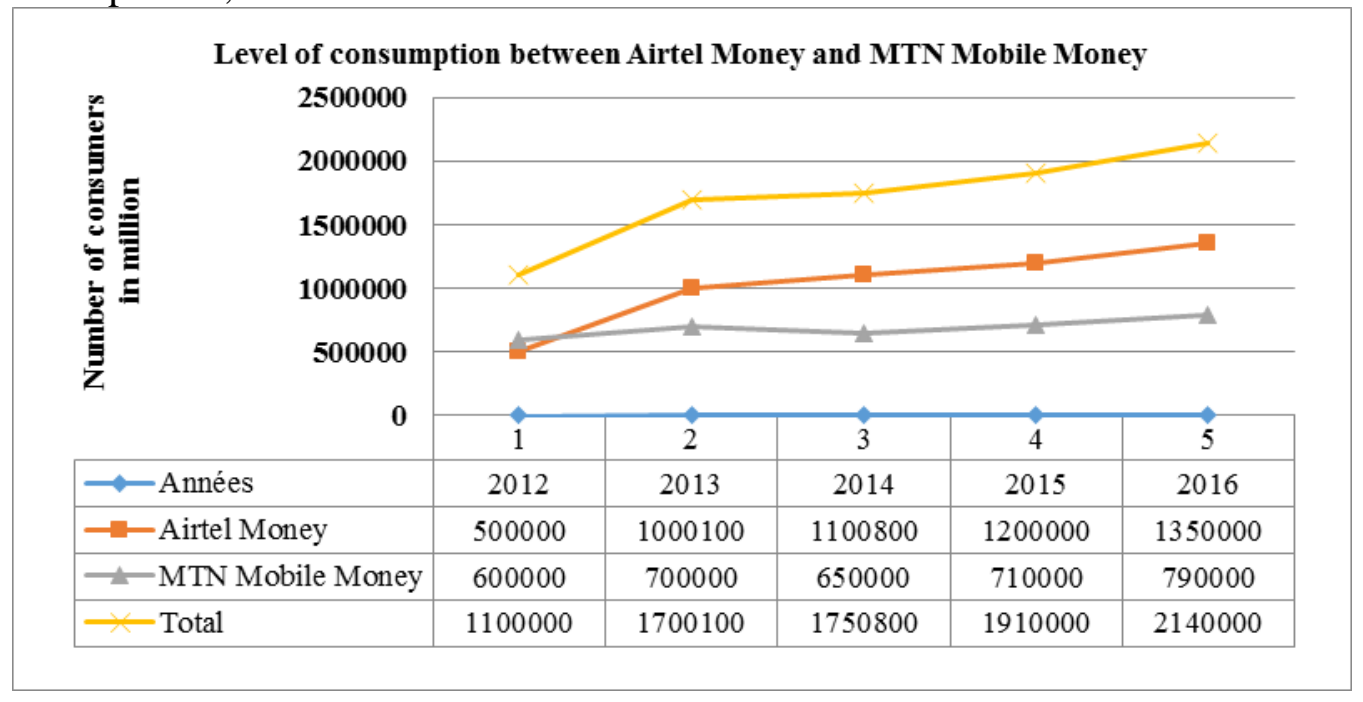

Fig. 3 Level of the consumption between Airtel Money and MTN Mobile Money

Note: Source: Author and ARPCE

This figure gives a clear and detailed representation the results of our analysis on the level of consumption of the competing products, Airtel Money and MTN Mobile Money, on Congolese mobile market, whose manufacturers are respectively Airtel Congo and MTN Congo.

* The first curve from top to bottom indicates the total number of consumers of these two products on the mobile phone market in Congo Brazzaville, starting from 2012 in 2016 . This curve shows clearly that consumption is increasing and/or evolving. With a figure of 110000 of consumers at the start, precisely in 2012, we note after 2012 a growth of the number of consumers from 1700100, 1750800, 1910000 , to 2140000 respectively.

* The second and third curves explain the level of growth of each product over the years. Our data and analysis show that in 2012 the MTN Mobile Money product occupied the first place ahead of Airtel money with 100,000 more consumers. Which means that MMM had got 600,000 loyal consumers and Airtel had 500,000. However, from 2013 until 2016, Airtel Money has taken over MTN Mobile Money in terms of consumers and impact on their competitive environment. Airtel Money therefore retains the leadership. To this end, it should be stressed out that this dominance or growth of consumers undoubtedly influences the turnover of Airtel Congo. Simply because the more this product is marketed, the more the company wins; meaning that it makes profit.

* The fourth curve simply places the two products in time (years). This curve allows know the chronological evolution of their life cycle (manufacture, growth and maturity ...). 


\section{Conclusion}

To sum up, after analysis of our research data on the impact of Airtel money in relation to the growth, image and turnover of Airtel Congo, it is clear that the "Airtel money" product contributes effectively to the formation of the turnover with a rate of $20 \%$. This makes it currently considered as the flagship product of Airtel Congo. Faced with its direct competitor "MTN Mobile Money", "Airtel money" leads widely the competition on the product in terms of the level of consumption. It should be remembered that Airtel money and MMM are similar products and are sold respectively by Airtel Congo and MTN Congo. The table and figures presented in this study clearly show that except 2012 when MMM made a record of 600,000 consumers or customers against 500,000 for Airtel money. However, for the rest of the years, i.e. from 2013 until 2016, Airtel money won it all with an exorbitant consumer score. Thus, it (Airtel Money) becomes master in front of its competitor and keeps carefully, fiercely its leadership in the market. In addition, according to the classic figure of product lifecycle, we note that Airtel Money is enjoying good growth although it has already reached the age or stage of maturity. This exponential increase in the number of consumers has a huge influence not only on the reputation the product itself but also on its manufacturer, Airtel Congo. The latter is becoming more and more famous, due to the increased consumption of the product Airtel Money. This adds value to the turnover of its manufacturer.

\section{Acknowledgement}

I would like to show my gratitude to Pr. Qin Yuanjian, Wuhan University of Technology for giving me a good guideline for assignment throughout numerous consultations. I would also like to expand my deepest gratitude to all those who have directly and indirectly guided us in writing this paper.

\section{References}

[1] C. Demeure. Aide-mémoire Marketing, Dunod, 6ème Edition, Paris, 2008, 402 Pages.

[2] Lendrevie, Levi and Lindon. Mercator, 9th edition, 2009, Page 225

[3] Yvan Valsecchi. Cours Complet de Marketing. Las Cresentinas, 2009, 584 pages, p.18

[4] M. D. S. Junior Ngomah. Investigation on strategies for products and services of Mobile phone companies in Congo Brazzaville (J) p. 123-133

[5] M. D. S. Junior Ngomah. Competition in the Air Transport Market in Congo. Line/ Pointe-Noire.

[6] ARPCE, annual statistical report on the mobile telephony market in the Congo, (2016)

[7] M. Poter, Competitive advantage, creating and sustaining superior performance, Free Press, 1998

[8] P. Kotler, K. Keller, D. Manceau. Marketing Management, 14th edition, (2012)

[9] E. Jerome McCarthy, Basic Marketing, a Managerial Approach, Richard D. Irwin, 1960. 